\author{
Alina Haczek \\ Uniwersytet Pedagogiczny \\ im. Komisji Edukacji Narodowej \\ w Krakowie
}

\title{
Funkcjonowanie bielskiego ośrodka akademickiego w warunkach globalizacji
}

Globalizację można najprościej zdefiniować jako wzrost zasięgu, wielości, różnorodności, szybkości i intensywności wzajemnych wpływów, zależności i oddziaływań między państwami oraz społecznościami. Jest ona procesem złożonym, wielowymiarowym, dotyczącym wszystkich dziedzin życia i w określony sposób wpływającym na kondycję ekonomiczną poszczególnych regionów, państw oraz społeczeństw. Głównym narzędziem, a zarazem nośnikiem współczesnej globalizacji jest postęp naukowo-techniczny, zwłaszcza w zakresie środków transportu i komunikacji. Jest on przyczyną niespotykanego w historii wzrostu efektywności gospodarowania (Polak 2009). Nowe technologie są coraz bardziej skomplikowane, wymagają coraz bardziej szczegółowej i wyspecjalizowanej wiedzy oraz umiejętności skumulowanych w kapitale ludzkim. Dlatego też, jak podkreśla wielu autorów (m.in. Denek 2001, Gnitecki 2002, Radło 2003, Janc 2004, Zioło 2008, Borowiec 2010) w warunkach postępującej globalizacji i rozwoju gospodarki opartej na wiedzy, niezwykle ważne jest podnoszenie jakości zasobów ludzkich. Inwestowanie w kapitał ludzki wpływa bowiem na zdolność jego szybkiej adaptacji do nowej rzeczywistości oraz stanowi podstawowy warunek trwałego wzrostu gospodarczego i postępu technicznego. Jednym z podstawowych czynników wpływających na podnoszenie jakości kapitału ludzkiego i kształtowanie społeczeństwa informacyjnego jest edukacja, zwłaszcza edukacja na poziomie wyższym. Dlatego też bardzo ważnym wyzwaniem, które powinno podjąć ,społeczeństwo globalne”, jest upowszechnienie szkolnictwa wyższego wraz z jego przystosowaniem do zmian cywilizacyjnych. Jednocześnie można stwierdzić, że w dobie nowoczesnych technologii, wynalazków, funkcjonowanie bez edukacji jest wręcz niemożliwe i odwrotnie. To ewolucja ekonomiczna napędza system edukacji, wymuszając na nim dokonywanie zmian i dostosowanie się do potrzeb rynku. Z drugiej strony natomiast to właśnie edukacja na wysokim poziomie pozwala na istnienie i rozwijanie się (Słobodzian 2001).

Szczególnego znaczenia w zakresie kształtowania jakości kapitału ludzkiego nabierają więc szkoły wyższe i ośrodki akademickie, których potencjał traktowany jest jako jeden z kluczowych czynników budowania nowoczesnej gospodarki. Zasoby ludzkie - wykształcone społeczeństwo o wysokich kwalifikacjach zawodowych, przedsiębiorcze i mobilne zawodowo - są fundamentem konkurencyjności i atrakcyjności regionu w globalnej gospodarce (Nowakowska, Boryczka 2008).

W nawiązaniu do powyższych przesłanek w artykule podjęto problematykę funkcjonowania bielskiego ośrodka akademickiego w warunkach globalizacji. Celem pracy jest przedstawienie zmian potencjału edukacyjnego ośrodka w latach 1969-2009, a także zmian kierunków 
kształcenia oraz ich dopasowanie do warunków nasilających się procesów globalizacji i nowoczesnej gospodarki. Ponadto zmierzać się będzie do ukazania zasięgu przestrzennego oddziaływania bielskiego ośrodka akademickiego określonego na podstawie miejsc stałego zamieszkania jego studentów w roku akademickim 2008/20091.

Bielski ośrodek akademicki funkcjonuje już przeszło 40 lat. Jego geneza związana jest bezpośrednio z dynamicznie rozwijającym się w latach powojennych bielskim przemysłem włókienniczym i elektromaszynowym. Ogromne zapotrzebowanie na wykształconych w tych dziedzinach specjalistów zrodziło potrzebę założenia w mieście pierwszych szkół wyższych. W 1966 r. utworzono w Bielsku-Białej zamiejscowy ośrodek ówczesnej Wyższej Szkoły Ekonomicznej w Katowicach (dzisiejszej Akademii Ekonomicznej im. K. Adamieckiego), a trzy lata później powstała bielska filia Politechniki Łódzkiej. Kolejne uczelnie, w większości niepubliczne, powstały w bielskim ośrodku akademickim w latach transformacji polityczno-gospodarczej. W wyniku długoletniego rozwoju szkolnictwa wyższego Bielsko-Biała stała się w pełni ukształtowanym i prężnie działającym ośrodkiem akademickim. Jedyną publiczną, samodzielnie działającą tutaj uczelnią, jest Akademia Techniczno-Humanistyczna, utworzona w 2001 r. z przekształcenia bielskiej filii Politechniki Łódzkiej. Oprócz niej działa tu także wspomniana wcześniej filia państwowej Akademii Ekonomicznej w Katowicach (Bielski Ośrodek Naukowo-Dydaktyczny Akademii Ekonomicznej w Katowicach), a także jedna szkoła posiadająca status kościelnej szkoły wyższej (Instytut Teologiczny w Bielsku-Białej). W bielskim ośrodku akademickim funkcjonuje również pięć niepublicznych szkół wyższych. Są to: Bielska Wyższa Szkoła im. J. Tyszkiewicza, Wyższa Szkoła Administracji, Wyższa Szkoła Bankowości i Finansów, Wyższa Szkoła Ekonomiczno-Humanistyczna oraz Wyższa Szkoła Informatyki i Zarządzania. Ponadto w Bielsku-Białej funkcjonuje Kolegium Nauczycielskie, które pod opieką naukowo-dydaktyczną kilku uczelni patronackich kształci przyszłych nauczycieli. Jest to jedna z największych placówek tego typu w Polsce, liczbą studentów dorównująca innym bielskim szkołom wyższym.

W konsekwencji kształtowania się bielskiego ośrodka akademickiego można zauważyć znaczące przemiany w liczbie studentów. W latach 1969-2009 ich liczba wzrosła z 225 do 15,8 tys., tj. prawie siedemdziesięciokrotnie (ryc. 1, tab. 1). Na podstawie analizy dynamiki liczby studentów bielskiego ośrodka akademickiego można wyróżnić cztery okresy. Okres pierwszy to lata akademickie 1969/1970-1977/1978, kiedy to liczba studentów wzrosła z 225 do 1,4 tys., czyli do 622,2\%. Był to czas gospodarki centralnie sterowanej, charakteryzujący się powszechną industrializacją, która w ogromnym stopniu zwiększyła zapotrzebowanie na wykształcone kadry dla prężnie rozwijającego się przemysłu, w przypadku Bielska-Białej dla przemysłu włókienniczego i elektromaszynowego. W drugim okresie, obejmującym lata akademickie 1977/1978-1986/1987, nastąpił spadek liczby studentów z 1,4 tys. do 509, tj. do 36,4\%. Sytuacja taka wywołana była wieloma różnorodnymi czynnikami społeczno-ekonomicznymi. Przede wszystkim ogólny kryzys gospodarczy spowodował znaczny spadek produkcji, a tym samym przyczynił się do zmniejszenia zapotrzebowania na kadry specjalistów. Ponadto pogarszające się warunki materialne ludności w zasadniczym stopniu wpłynęły na obniżenie presji społecznej w dążeniu do uzyskania wyższego wykształcenia. Na te czynniki dodatkowo nałożył się niż demograficzny grupy wiekowej typowej dla kandydatów na studia wyższe, skutkując znacznym obniżeniem liczby studentów nie tylko w bielskim ośrodku akademickim, ale także w całej Polsce (Kluczyński 1991).

\footnotetext{
${ }^{1}$ Prezentowane wyniki badań pochodzą z pracy magisterskiej autorki artykułu pt. Rozwój i przestrzenne oddziaływanie bielskiego ośrodka akademickiego napisanej pod kierunkiem prof. dr hab. inż. E. Kaczmarskiej oraz dr M. Borowiec w roku akademickim 2009/2010.
} 
Ryc. 1. Zmiany liczby studentów w bielskim ośrodku akademickim w latach 1969-2009

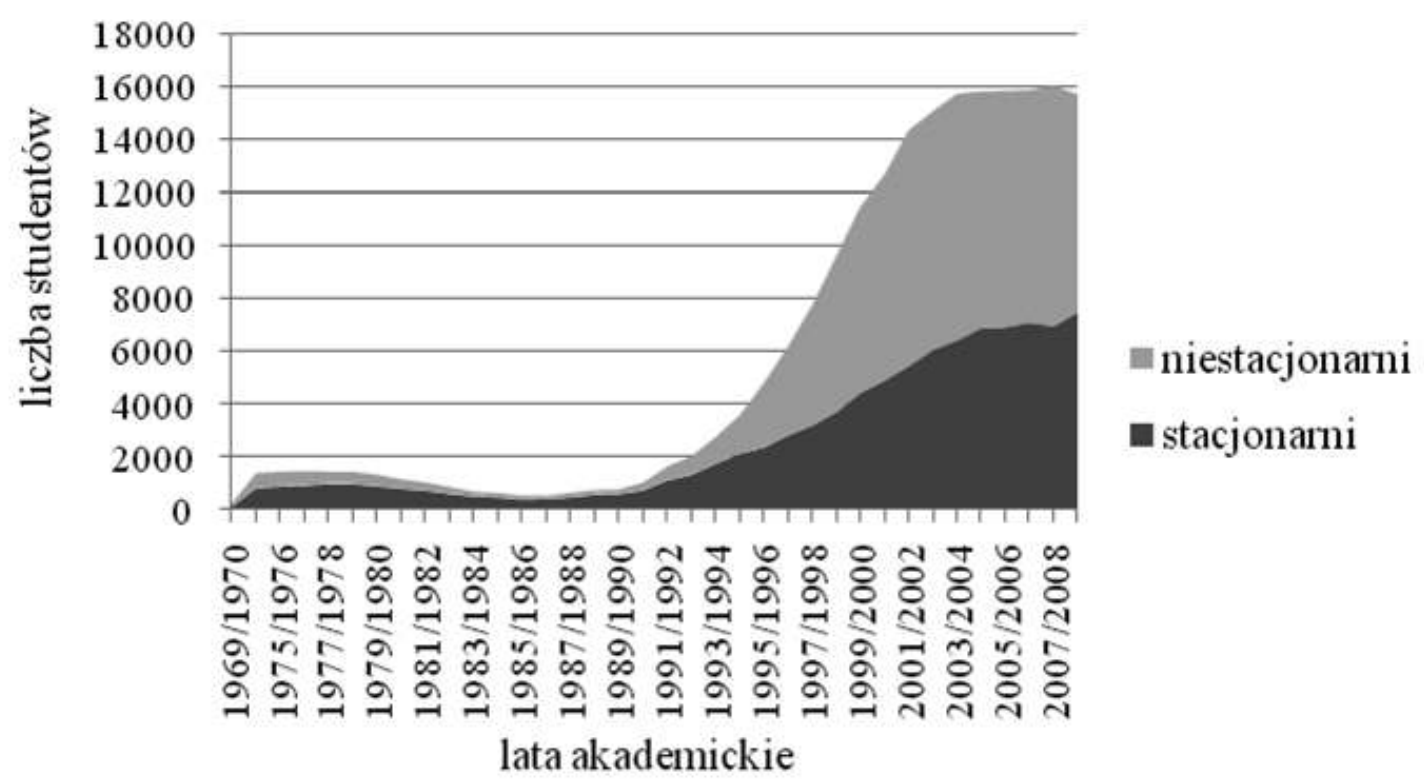

Źródło: opracowanie własne na podstawie tabeli 1.

Trzeci okres charakteryzował się dynamicznym wzrostem liczby studentów z 509 w roku akademickim 1986/1987 do 16,1 tys. w 2007/2008, czyli aż do 3163,1\%. Na taką sytuację wpłynęły głównie licznie powstające po 1990 r. szkoły wyższe. Uczelnie te, w większości przypadków niepubliczne, zwiększyły dostęp do edukacji na poziomie wyższym. Ponadto, pod wpływem przemian społeczno-gospodarczych w naszym kraju, diametralnie zmieniło się nastawienie do studiów wyższych. Dla wielu młodych ludzi stały się one szansą podniesienia kwalifikacji, a tym samym gwarantem znalezienia lepszej pracy w przyszłości. Natomiast w ostatnim badanym roku akademickim: 2008/2009, w porównaniu z rokiem poprzednim zaznaczył się spadek liczby studentów o 325 osób, tj. do 98,0\%. Jest to pierwsza oznaka wchodzenia w wiek typowy dla kandydatów na studia roczników z niżu demograficznego. Dlatego też można przypuszczać, iż w ciągu następnych kilku lat liczba studentów bielskiego ośrodka akademickiego będzie charakteryzowała się tendencją spadkową.

Na zróżnicowanie dynamiki liczby studentów w latach 1969-2009 zmienny wpływ mieli zarówno studenci studiów stacjonarnych, jak i studiów niestacjonarnych (ryc. 1, tab. 1). W pierwszym wyróżnionym okresie liczba studentów stacjonarnych zwiększyła się ze 127 w roku akademickim 1969/1970 do 978 w roku akademickim 1977/1978, czyli do 770,1\%. Równocześnie liczba studentów niestacjonarnych wzrosła z 98 w roku akademickim 1969/1970 do 547 w roku akademickim 1974/75, czyli do 558,1\%, a w ciągu następnych trzech lat zanotowano ich nieznaczny spadek do $448 \mathrm{w}$ roku akademickim 1977/1978, tj. do 457,1\%. Jednocześnie można zauważyć, że w badanym okresie czasu wyższą dynamiką wzrostu liczby studentów charakteryzowali się studenci studiów stacjonarnych, co odzwierciedla zwiększenie się ich udziału w ogólnej liczbie studentów z 56,4\% w roku akademickim 1969/1970 do 68,6\% w roku akademickim 1977/1978. W drugim okresie czasu nastąpił znaczny spadek liczby studentów zarówno studiów stacjonarnych, jak i studiów niestacjonarnych. W pierwszej z tych grup zaznaczył się spadek z 978 studentów w roku akademickim 1977/1978 do 412 w roku 1986/1987, czyli do 42,1\%. Natomiast w przypadku studentów niestacjonarnych zanotowano spadek z 448 w 1977/1978 do 97 studiujących w 1986/1987, czyli do 21,6\%. W analizowanym okresie czasu zwiększył się udział studentów stacjonarnych w ogólnej liczbie studentów 
bielskiego ośrodka akademickiego z 68,6\% w 1977/1978 do 80,0\% w roku akademickim 1986/1987. W trzecim okresie liczba studentów stacjonarnych wzrosła z $412 \mathrm{w}$ roku akademickim 1986/1987 do 6,9 tys. w 2007/2008, czyli do 1 674,8\%, natomiast w wypadku studentów studiów niestacjonarnych w tych samych latach akademickich zanotowano wzrost z 97 do 9,1 tys., tj. do 9 381,4\%. Warto zauważyć, że w badanym okresie, przeciwnie do okresów wcześniejszych, dynamika wzrostu liczby studentów niestacjonarnych była wyższa niż studentów stacjonarnych. Wyrazem tego procesu jest zwiększenie się udziału liczby studentów niestacjonarnych w ogólnej liczbie studentów bielskich uczelni z 19,1\% w roku akademickim 1986/1987 do 56,8\% w roku 2007/2008. Taka diametralna zmiana wynika ze zmieniających się warunków na rynku pracy. Obecnie samo wyższe wykształcenie nie gwarantuje znalezienia dobrze płatnej i atrakcyjnej pracy. Coraz bardziej liczą się za to zdobyte umiejętności i doświadczenie zawodowe. Dlatego też wiele młodych ludzi podejmuje studia niestacjonarne i równocześnie odbywa staż zawodowy, bardzo pożądany, a niekiedy wręcz wymagany przez przyszłych pracodowaców. Doświadczenie zawodowe zdobyte podczas studiów czyni ich w przyszłości bardziej konkurencyjnymi na rynku pracy w stosunku do osób kończących studia trybem stacjonornym i nieposiadających odpowiedniego przygotowania praktycznego. Ostatni badany rok akademicki (2008/2009) charakteryzował się niewielkim wzrostem liczby studentów stacjonarnych z 6,9 tys. w roku poprzednim do 7,5 tys., tj. do 108,7\%. Odwrotna sytuacja dotyczyła natomiast studentów niestacjonarnych, gdyż ich liczba spadła z 9,1 tys. w roku akademickim 2007/2008 do 8,3 tys. w roku 2008/2009, czyli do $91,2 \%$. Ponadto w porównaniu z rokiem poprzednim nieznacznie zmniejszył się ich udział w ogólnej liczbie studentów z 56,8\% do 52,5\%.

Tab. 1. Zmiany liczby studentów w bielskim ośrodku akademickim w latach 1969-2009

\begin{tabular}{|c|c|c|c|c|c|c|c|c|}
\hline \multirow[b]{2}{*}{$\begin{array}{c}\text { Lata } \\
\text { akademickie }\end{array}$} & \multicolumn{3}{|c|}{ Liczba studentów } & \multicolumn{2}{|c|}{ Udzial studentów } & \multicolumn{3}{|c|}{ Dynamika liczby studentów } \\
\hline & $\frac{1}{0}$ & 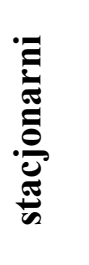 & 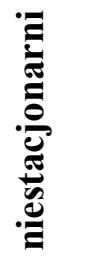 & 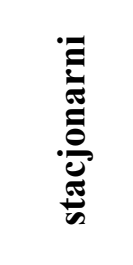 & 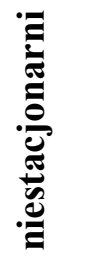 & $\frac{1}{0}$ & 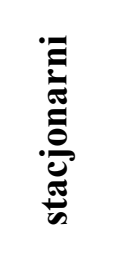 & 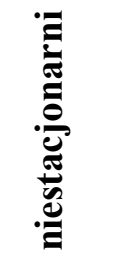 \\
\hline $1969 / 1970$ & 225 & 127 & 98 & 56,4 & 43,6 & 100,0 & 100,0 & 100,0 \\
\hline $1974 / 1975$ & 1372 & 825 & 547 & 60,1 & 39,9 & 609,8 & 649,6 & 558,2 \\
\hline $1975 / 1976$ & 1422 & 879 & 543 & 61,8 & 38,2 & 632,0 & 692,1 & 554,1 \\
\hline $1976 / 1977$ & 1450 & 915 & 535 & 63,1 & 36,9 & 644,4 & 720,5 & 545,9 \\
\hline $1977 / 1978$ & 1426 & 978 & 448 & 68,6 & 31,4 & 633,8 & 770,1 & 457,1 \\
\hline $1978 / 1979$ & 1424 & 973 & 451 & 68,3 & 31,7 & 632,9 & 766,1 & 460,2 \\
\hline $1979 / 1980$ & 1314 & 887 & 427 & 67,5 & 32,5 & 584,0 & 698,4 & 435,7 \\
\hline $1980 / 1981$ & 1136 & 796 & 340 & 70,1 & 29,9 & 504,9 & 626,8 & 346,9 \\
\hline $1981 / 1982$ & 1014 & 723 & 291 & 71,3 & 28,7 & 450,7 & 569,3 & 296,9 \\
\hline $1982 / 1983$ & 841 & 603 & 238 & 71,7 & 28,3 & 373,8 & 474,8 & 242,9 \\
\hline $1983 / 1984$ & 667 & 510 & 157 & 76,5 & 23,5 & 296,4 & 401,6 & 160,2 \\
\hline $1984 / 1985$ & 615 & 470 & 145 & 76,4 & 23,6 & 273,3 & 370,1 & 148,0 \\
\hline
\end{tabular}




\begin{tabular}{|c|c|c|c|c|c|c|c|c|}
\hline \multirow[b]{2}{*}{$\begin{array}{c}\text { Lata } \\
\text { akademickie }\end{array}$} & \multicolumn{3}{|c|}{ Liczba studentów } & \multicolumn{2}{|c|}{ Udzial studentów } & \multicolumn{3}{|c|}{ Dynamika liczby studentów } \\
\hline & $\frac{\Xi}{0}$ & 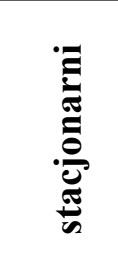 & 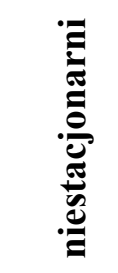 & 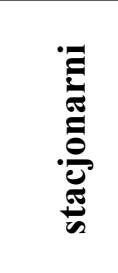 & 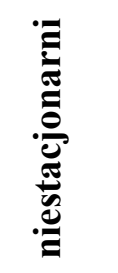 & $\frac{\Xi}{0}$ & 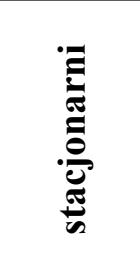 & 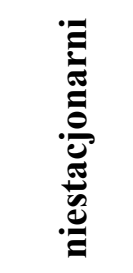 \\
\hline $1985 / 1986$ & 517 & 387 & 130 & 74,9 & 25,1 & 229,8 & 304,7 & 132,7 \\
\hline $1986 / 1987$ & 509 & 412 & 97 & 80,9 & 19,1 & 226,2 & 324,4 & 99,0 \\
\hline $1987 / 1988$ & 621 & 472 & 149 & 76,0 & 24,0 & 276,0 & 371,7 & 152,0 \\
\hline $1988 / 1989$ & 725 & 570 & 155 & 78,6 & 21,4 & 322,2 & 448,8 & 158,2 \\
\hline $1989 / 1990$ & 753 & 595 & 158 & 79,0 & 21,0 & 334,7 & 468,5 & 161,2 \\
\hline $1990 / 1991$ & 1006 & 734 & 272 & 73,0 & 27,0 & 447,1 & 578,0 & 277,6 \\
\hline $1991 / 1992$ & 1615 & 1113 & 502 & 68,9 & 31,1 & 717,8 & 876,4 & 512,2 \\
\hline $1992 / 1993$ & 2006 & 1321 & 685 & 65,9 & 34,1 & 891,6 & 1040,2 & 699,0 \\
\hline $1993 / 1994$ & 2737 & 1740 & 997 & 63,6 & 36,4 & 1216,4 & 1370,1 & 1017,3 \\
\hline $1994 / 1995$ & 3576 & 2121 & 1455 & 59,3 & 40,7 & 1589,3 & 1670,1 & 1484,7 \\
\hline $1995 / 1996$ & 4789 & 2351 & 2438 & 49,1 & 50,9 & 2128,4 & 1851,2 & 2487,8 \\
\hline $1996 / 1997$ & 6184 & 2814 & 3370 & 45,5 & 54,5 & 2748,4 & 2215,7 & 3438,8 \\
\hline $1997 / 1998$ & 7752 & 3191 & 4561 & 41,2 & 58,8 & 3445,3 & 2512,6 & 4654,1 \\
\hline $1998 / 1999$ & 9634 & 3697 & 5937 & 38,4 & 61,6 & 4281,8 & 2911,0 & 6058,2 \\
\hline $1999 / 2000$ & 11512 & 4425 & 7087 & 38,4 & 61,6 & 5116,4 & 3484,3 & 7231,6 \\
\hline $2000 / 2001$ & 12696 & 4893 & 7803 & 38,5 & 61,5 & 5642,7 & 3852,8 & 7962,2 \\
\hline $2001 / 2002$ & 14392 & 5444 & 8948 & 37,8 & 62,2 & 6396,4 & 4286,6 & 9130,6 \\
\hline $2002 / 2003$ & 15112 & 6064 & 9048 & 40,1 & 59,9 & 6716,4 & 4774,8 & 9232,7 \\
\hline $2003 / 2004$ & 15775 & 6414 & 9361 & 40,7 & 59,3 & 7011,1 & 5050,4 & 9552,0 \\
\hline $2004 / 2005$ & 15861 & 6877 & 8984 & 43,4 & 56,6 & 7049,3 & 5415,0 & 9167,3 \\
\hline $2005 / 2006$ & 15893 & 6914 & 8979 & 43,5 & 56,5 & 7063,6 & 5444,1 & 9162,2 \\
\hline $2006 / 2007$ & 15912 & 7090 & 8822 & 44,6 & 55,4 & 7072,0 & 5582,7 & 9002,0 \\
\hline $2007 / 2008$ & 16080 & 6951 & 9129 & 43,2 & 56,8 & 7146,7 & 5473,2 & 9315,3 \\
\hline $2008 / 2009$ & 15755 & 7483 & 8272 & 47,5 & 52,5 & 7002,2 & 5892,1 & 8440,8 \\
\hline
\end{tabular}

Źródło: opracowanie własne na podstawie danych uzyskanych w dziekanatach bielskich uczelni.

Jednym z podstawowych wyzwań, które globalizacja stawia przed szkolnictwem wyższym, jest dopasowanie kierunków kształcenia do wymogów nowoczesnej gospodarki i coraz bardziej wymagającego rynku pracy. W związku z dynamicznym postępem naukowo-technicznym 
szczególnie ważny jest rozwój nauk ścisłych, głównie technicznych i inżynieryjnych. Niezwykle istotny jest także rozwój filologii, zwłaszcza filologii angielskiej, gdyż pod wpływem zachodzących procesów globalizacji język ten stał się językiem globalnym. Umożliwia on komunikowanie się ludźmi, dominuje również w różnego rodzaju publikacjach naukowych, stając się fundamentem funkcjonowania w ,globalnej wiosce". Na potrzeby niniejszej pracy spośród różnorodnych kierunków oferowanych przez bielskie szkoły wyższe wybrano tylko tzw. kierunki nośne współczesnej globalizacji, które są podstawą rozwoju technologicznego i wdrażania innowacji. Są to: automatyka i robotyka, informatyka, inżynieria środowiska, mechanika i budowa maszyn, zarządzanie i inżynieria produkcji oraz wspomniana już wcześniej filologia angielska².

Ryc. 2. Zmiany liczby studentów na wybranych kierunkach kształcenia bielskiego ośrodka akademickiego w latach 1969-2009

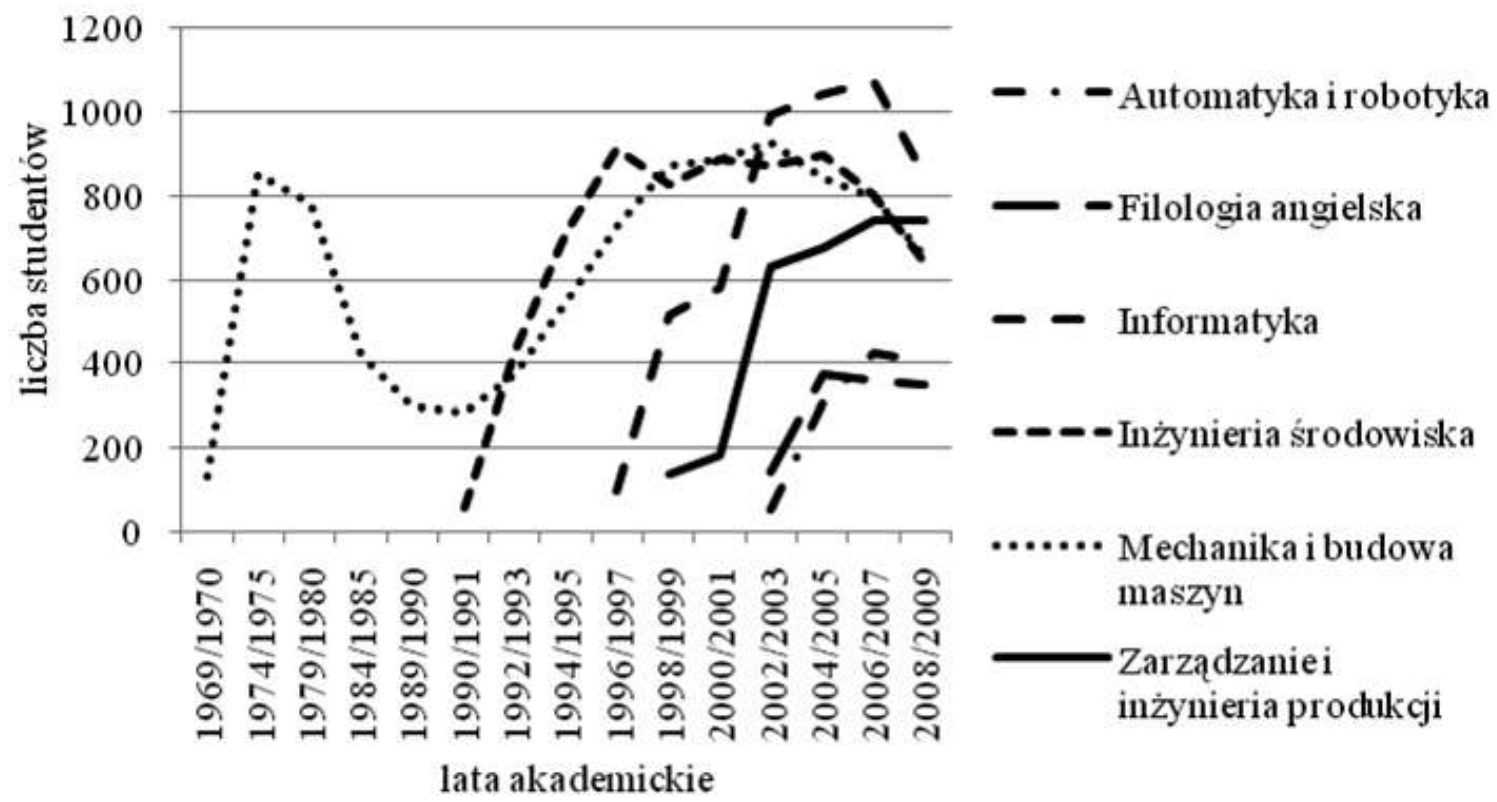

Źródło: opracowanie własne na podstawie tabeli 2.

Wszystkie te kierunki charakteryzowały się bardzo dużą dynamiką wzrostu liczby studentów, zwłaszcza w latach transformacji gospodarki narodowej (ryc. 2, tab. 2). Najwyższa dynamika liczby studentów cechowała inżynierię środowiska. Liczba studentów tego kierunku wzrosła z 55 w roku akademickim 1990/1991 do 912 w roku 1996/1997, czyli do 1658,2\%, a następnie zaznaczył się spadek do 639 w roku 2008/2009, czyli do 70,1\%. Na drugim miejscu znalazła się informatyka. Liczba studentów tego kierunku wzrosła z 95 w roku akademickim 1996/1997 do 1073 w roku 2006/2007, czyli do 1129,5\%. Natomiast w ostatnich latach zaznaczył się spadek liczby studentów informatyki z 1073 w roku 2006/2007 do 848 w roku 2008/2009, czyli do $79 \%$. W ramach obu wymienionych kierunków funkcjonują nowoczesne specjalizacje, tj. technologie materiałowe w inżynierii środowiska oraz telekomunikacja i sieci komputerowe $\mathrm{w}$ informatyce.

${ }^{2}$ Ze względu na trudności z uzyskaniem danych poniższa analiza obejmuje kierunki kształcenia oferowane tylko przez pięć bielskich szkół wyższych (Akademię Techniczno-Humanistyczną, Akademię Ekonomiczną, Instytut Teologiczny, Bielską Wyższą Szkołę im. J. Tyszkiewicza oraz Kolegium Nauczycielskie). 
Tab. 2. Zmiany liczby studentów na wybranych kierunkach bielskiego ośrodka akademickiego w latach 1969-2009

\begin{tabular}{|c|c|c|c|c|c|c|}
\hline $\begin{array}{c}\text { Lata } \\
\text { akademickie }\end{array}$ & $\begin{array}{c}\text { Automatyka } \\
\text { i robotyka }\end{array}$ & $\begin{array}{c}\text { Filologia } \\
\text { angielska }\end{array}$ & Informatyka & $\begin{array}{c}\text { Inżynieria } \\
\text { śodowiska }\end{array}$ & $\begin{array}{c}\text { Mechanika } \\
\text { i budowa } \\
\text { maszyn }\end{array}$ & $\begin{array}{c}\text { Zarządzanie } \\
\text { i inżynieria } \\
\text { produkcji }\end{array}$ \\
\hline $1969 / 1970$ & - & - & - & - & 134 & - \\
\hline $1974 / 1975$ & - & - & - & - & 852 & - \\
\hline $1979 / 1980$ & - & - & - & - & 780 & - \\
\hline $1984 / 1985$ & - & - & - & - & 419 & - \\
\hline $1989 / 1990$ & - & - & - & - & 300 & - \\
\hline $1990 / 1991$ & - & - & - & 55 & 283 & - \\
\hline $1992 / 1993$ & - & - & - & 429 & 374 & - \\
\hline $1994 / 1995$ & - & - & - & 712 & 545 & - \\
\hline $1996 / 1997$ & - & - & 95 & 912 & 728 & - \\
\hline $1998 / 1999$ & - & - & 512 & 826 & 870 & 138 \\
\hline $2000 / 2001$ & - & - & 580 & 887 & 886 & 183 \\
\hline $2002 / 2003$ & 50 & 141 & 990 & 874 & 927 & 628 \\
\hline $2004 / 2005$ & 308 & 376 & 1043 & 897 & 841 & 673 \\
\hline $2006 / 2007$ & 422 & 361 & 1073 & 799 & 796 & 742 \\
\hline $2008 / 2009$ & 403 & 346 & 848 & 639 & 655 & 739 \\
\hline
\end{tabular}

Źródło: opracowanie własne na podstawie danych uzyskanych w dziekanatach bielskich uczelni.

Najstarszym spośród omawianych kierunków jest mechanika i budowa maszyn. W pierwszym roku akademickim (1960/1970) studiowały ją 134 osoby i ich liczba systematycznie rosła aż do 852 w roku 1974/1975, czyli do 635,8\%. Następnie zaznaczył się spadek liczby studentów tego kierunku z 852 w roku 1974/1975 do 283 w roku 1990/1991, czyli do 33,2\%, związany z ogólnym kryzysem gospodarczym w całym kraju. Następne lata przyniosły wzrost liczby studentów z 283 w roku 1990/1991 do 927 w roku akademickim 2002/2003, czyli do $327,6 \%$. Od tego roku liczba studentów mechaniki i budowy maszyn charakteryzowała się tendencją malejącą. W latach 2002/2003-2008/2009 ich liczba spadła z 927 do 655, tj. do 70,7\%. Absolwenci tego kierunku dysponują szeroką wiedzą z zakresu budowy, konstrukcji i eksploatacji maszyn dla różnych sektorów produkcji przemysłowej, a także, dzięki prowadzonej specjalizacji, umiejętnościami wykorzystania nowoczesnych narzędzi komputerowych w projektach inżynierskich.

Kolejnym wyróżnionym kierunkiem jest automatyka i robotyka. Liczba studentów tego kierunku w latach akademickich 2002/2003-2006/2007 wzrosła z 50 do 422, czyli do 844\%. Następnie ich liczba spadła z 422 w roku 2006/2007 do 403 w roku 2008/2009, czyli do 95,5\%. Automatyka i robotyka jest nowoczesnym i przyszłościowym kierunkiem studiów, w ramach którego studenci uczą się sterowania procesami technologicznymi za pomocą urządzeń różnego rodzaju, a dzięki swojej wiedzy mają możliwość uzyskania atrakcyjnej pracy. 
Natomiast liczba studentów kolejnego kierunku - filologii angielskiej - wzrosła ze $141 \mathrm{w}$ roku akademickim 2002/2003 do 376 w roku akademickim 2004/2005, czyli do 266,7\%, a następnie spadła do 346 w roku akademickim 2008/2009, czyli do 92,0\%. Ostatnim wyróżnionym kierunkiem studiów jest zarządzanie i inżynieria produkcji. Liczba studentów tego kierunku zwiększyła się ze 138 w roku akademickim 1998/1999 do 742 w roku 2006/2007, czyli do 537,7\%, a następnie zaznaczył się ich niewielki spadek do 739 w roku 2008/2009, czyli do 99,6\%. Absolwenci tego kierunku studiów posiadają bogate umiejętności menedżerskie pozwalające im na kierowanie personelem oraz projektowanie, organizowanie i zarządzanie procesem produkcyjnym. Ponadto w ramach studiów studenci mogą wybrać nowoczesną specjalizację, jaką są informatyczne systemy zarządzania.

Analizując dynamikę liczby studentów na wyszczególnionych kierunkach studiów, należy zauważyć, że na wszystkich z nich w ciągu kilku ostatnich lat nastąpił spadek liczby studentów. Z jednej strony sytuacja taka może wynikać z omawianego już wcześniej niżu demograficznego i mniejszej podaży kandydatów na studia, a z drugiej strony związana jest z powstawaniem nowych kierunków studiów, w większości humanistycznych, a zarazem modą na takie kierunki studiów. Przykładem mogą być architektura krajobrazu, filologia słowiańska, filologia hiszpańska, pielęgniarstwo, charakteryzujące się w ostatnich latach dużą dynamiką wzrostu liczby studentów oraz coraz większym zainteresowaniem przyszłych kandydatów na studia (ryc. 3.). Liczba studentów architektury krajobrazu wzrosła w latach 2006/2007-2008/2009 z 21 do 162, czyli do 771,4\%. Podobnie liczba studentów pielęgniarstwa w tych samych latach wzrosła z 284 do 324, czyli do 114,1\%. Natomiast liczba studentów filologii słowiańskiej zwiększyła się z 148 w roku 2002/2003 do $415 \mathrm{w}$ roku 2008/2009, czyli do 280,4\%, a liczba studentów filologii hiszpańskiej wzrosła w latach 2004/2005-2008/2009 z 47 do 193, czyli do 410,6\%.

Ryc. 3. Zmiany liczby studentów na wybranych kierunkach studiów bielskiego ośrodka akademickiego w latach 1969-2009

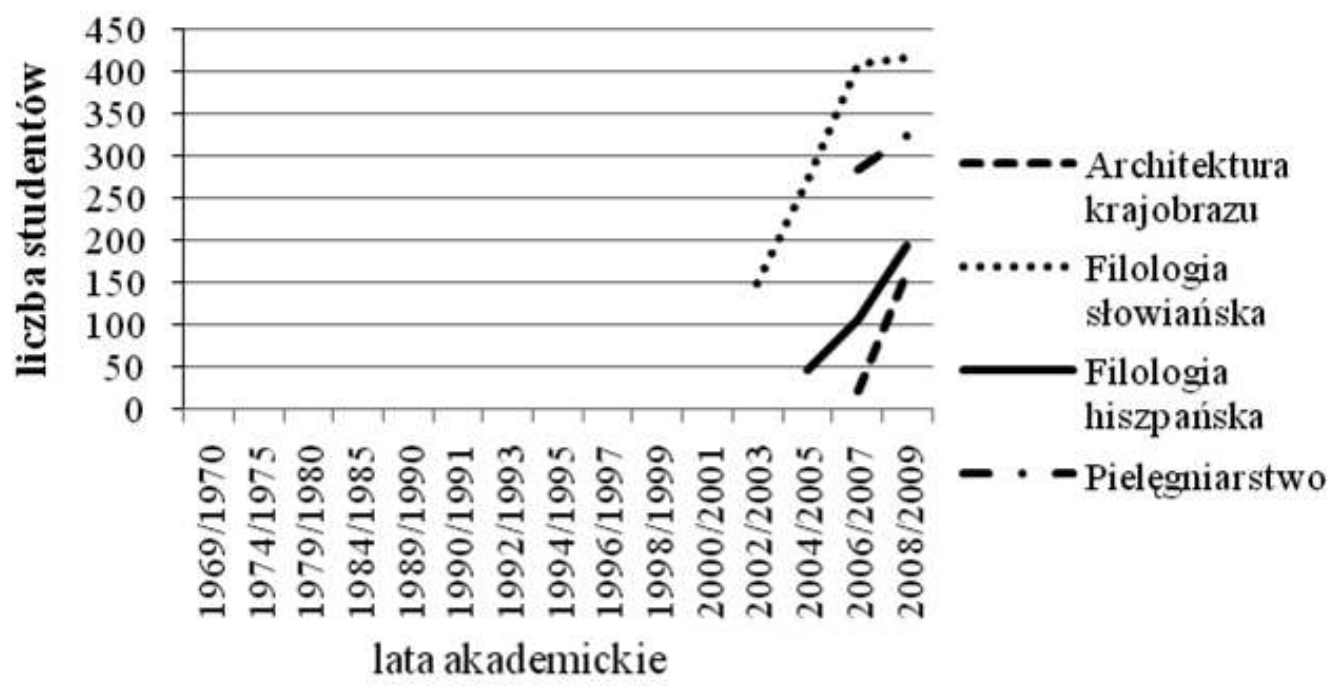

Źródło: opracowanie własne na podstawie danych uzyskanych w dziekanatach bielskich uczelni.

Spośród wybranych sześciu kierunków studiów w roku akademickim 2008/2009 największą liczbę studentów skupiała informatyka $(7,9 \%)$ oraz zarządzanie i inżynieria produkcji $(6,9 \%)$. Następne kierunki pod względem liczby studentów to mechanika i budowa maszyn $(6,1 \%)$, inżynieria środowiska $(6,0 \%)$, automatyka i robotyka $(3,8 \%)$. Najmniejsza grupa studentów kształciła się na filologii angielskiej (3,2\%). 
Pomimo faktu, iż dynamika wzrostu liczby studentów na tych kierunkach była bardzo wysoka w ciągu ostatnich 20 lat, to łącznie kierunki te w roku akademickim 2008/2009 skupiały tylko 33,8\% studentów. Dlatego przed bielskimi uczelniami wyższymi stoi trudne zadanie zachęcenia przyszłych kandydatów na studia do podjęcia nauki na tych ważnych z punktu widzenia rozwoju gospodarczego i postępujących procesów globalizacji kierunkach. Takie działanie podejmuje na przykład Akademia Techniczno-Humanistyczna, która wprowadziła w zeszłym i obecnym roku akademickim (2009/2010 i 2010/2011) nowe kierunki studiów, takie jak budownictwo czy transport. Ponadto uczelnia w ramach Poddziałania 4.1.2 Zwiększenie liczby absolwentów kierunków o kluczowym znaczeniu dla gospodarki opartej na wiedzy Programu Operacyjnego Kapitał Ludzki realizuje projekt „Inżynier na miarę XXI wieku". Objęto nim mechanikę i budowę maszyn, automatykę i robotykę, informatykę oraz inżynierię środowiska jako kierunki kluczowe dla rozwoju gospodarki opartej na wiedzy. Celem tego projektu jest powiązanie bielskiego szkolnictwa wyższego z lokalną gospodarką i zapotrzebowaniem lokalnego rynku pracy ${ }^{3}$.

Ryc. 4. Struktura kierunków kształcenia bielskiego ośrodka akademickiego w roku akademickim $2008 / 2009$

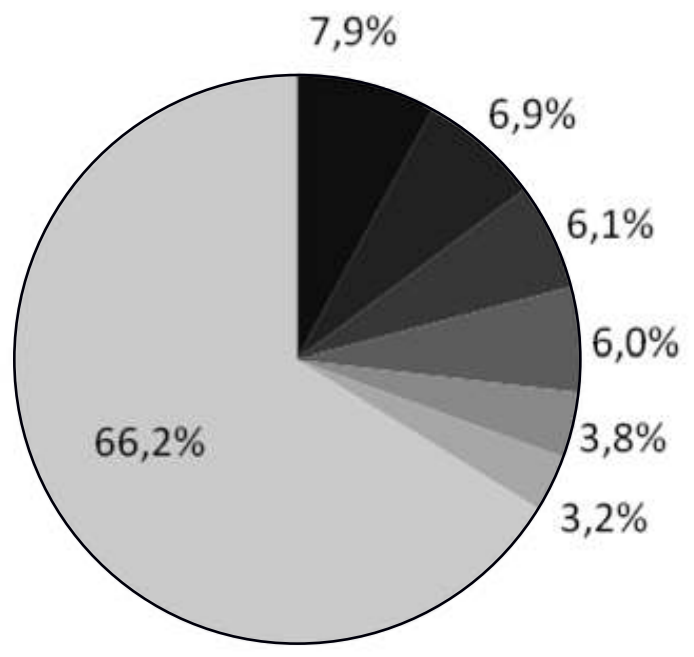

\author{
- Informatyka \\ Zarządzanie i inżynieria \\ produkcji \\ Mechanikai budowa \\ maszyn \\ Inżynieria środowiska \\ Automatyka i robotyka \\ Filologia angielska \\ Pozostałe kierunki
}

Źródło: opracowanie własne na podstawie danych uzyskanych w dziekanatach bielskich uczelni.

Omawiając funkcjonowanie danego ośrodka akademickiego, należy również zwrócić uwagę na jest jego przestrzenne oddziaływanie. Świadczy ono bowiem o zasięgu kształtowania zasobów intelektualnych tego ośrodka zarówno w przestrzeni lokalnej, jak i regionalnej. Niniejsze zestawienie przygotowano na podstawie danych dotyczących miejsca stałego zamieszkania studentów, uzyskanych w dziekanatach poszczególnych bielskich szkół wyższych ${ }^{4}$. Studenci bielskiego ośrodka akademickiego w roku 2008/2009 rekrutowali się prawie ze

\footnotetext{
${ }^{3}$ Informację o projekcie oraz szczegóły dotyczące realizowanych kierunków studiów zaczerpnięto ze strony internetowej Akademii Techniczno-Humanistycznej http://info.ath.bielsko.pl/

${ }^{4}$ Niniejsza analiza została przeprowadzona na podstawie danych jednostkowych uzyskanych w dziekanatach bielskich szkół wyższych i obejmuje studentów pierwszego roku Akademii Techniczno-Humanistycznej, studentów pierwszego roku Kolegium Nauczycielskiego oraz studentów Bielskiej Wyższej Szkoły im. J. Tyszkiewicza, Instytutu Teologicznego oraz Akademii Ekonomicznej. Łącznie badana grupa osób obejmuje 25,6\% bielskich studentów w roku akademickim 2008/2009.
} 
wszystkich województw za wyjątkiem województwa zachodniopomorskiego. Dominujące znaczenie w tym względzie miało województwo śląskie, z którego pochodziło 3454 studentów - stanowili oni $85,6 \%$ ogólnej liczby badanych studentów. Kolejną pozycję zajmowało województwo małopolskie, z którego rekrutowało się 528 studentów, czyli 13,1\% ich ogólnej liczby. Łącznie z tych dwóch województw pochodziło 3982 studentów, którzy stanowili aż 98,7\% ogółu badanych osób. Pozostałe województwa miały marginalne znaczenie w zakresie pochodzenia studentów bielskich uczelni. Z każdego z nich rekrutowało się od jednego do dziewięciu studentów, co stanowi od 0,02\% do 0,22\% ich ogólnej liczby. Łącznie z tych 13 województw pochodziło 55 studentów, czyli 1,3\% ich ogólnej liczby.

Tab. 3. Koncentracja osadnicza studentów bielskich szkół wyższych w roku akademickim 2008/2009

\begin{tabular}{|c|c|c|c|c|}
\hline $\begin{array}{c}\text { Przedziały liczby } \\
\text { studentów }\end{array}$ & $\begin{array}{c}\text { Liczba } \\
\text { jednostek } \\
\text { (gmin) }\end{array}$ & $\begin{array}{c}\text { Liczba } \\
\text { studentów }\end{array}$ & $\begin{array}{c}\text { Struktura } \\
\text { jednostek (gmin) }\end{array}$ & $\begin{array}{c}\text { Struktura } \\
\text { studentów }\end{array}$ \\
\hline 1 & 94 & 94 & 44,76 & 2,33 \\
\hline 2 & 21 & 42 & 10,00 & 1,04 \\
\hline $3-5$ & 26 & 103 & 12,38 & 2,55 \\
\hline $6-10$ & 16 & 123 & 7,62 & 3,05 \\
\hline $11-30$ & 20 & 409 & 9,52 & 10,13 \\
\hline $31-50$ & 14 & 539 & 6,67 & 13,35 \\
\hline $51-70$ & 5 & 299 & 2,38 & 7,41 \\
\hline $71-100$ & 7 & 624 & 3,33 & 15,46 \\
\hline $101-200$ & 6 & 801 & 2,86 & 19,84 \\
\hline $201-1100$ & 1 & 1003 & 0,48 & 24,85 \\
\hline Ogółem & 210 & 4037 & 100,00 & 100,00 \\
\hline
\end{tabular}

Źródło: opracowanie własne na podstawie danych jednostkowych uzyskanych w dziekanatach bielskich uczelni.

Natomiast na podstawie analizy gmin, z których rekrutowali się bielscy studenci, można stwierdzić, że w roku akademickim 2008/2009 rekrutowali się oni z 210 różnych gmin (tab. 3 ). Dominujące znaczenie w tym względzie miała gmina Bielsko-Biała. Pochodziło z niej 1003 studentów, którzy stanowili 24,8\% ich ogólnej liczby, podczas gdy sama Bielsko-Biała stanowiła tylko 0,48\% ogólnej liczby gmin. Kolejną pozycję zajmowały Czechowice-Dziedzice, Żywiec, Jasienica Pszczyna, Cieszyn i Kęty, z których rekrutowało się od 101 do 200 studentów, a łącznie pochodziło z nich 19,8\% ich ogólnej liczby, podczas gdy stanowiły one 2,9\% badanych gmin. Następne były Andrychów, Wilamowice, Radziechowy-Wieprz, Kozy, Skoczów, Węgierska Górka i Porąbka, z których łącznie pochodziło 15,6\% wszystkich badanych studentów, a stanowiły one tylko 3,33\% wszystkich gmin. Wszystkie wymienione wyżej gminy odgrywały kluczową rolę w zakresie rekrutacji studentów, ponieważ łącznie pochodziło z nich aż 60,1\% wszystkich studentów.

Wyrazem relacji między udziałem studentów i jednostek osadniczych, z których się oni rekrutują, jest wysoka wartość wskaźnika koncentracji osadniczej studentów, która w roku 
akademickim 2008/2009 wyniosła 0,658. Wskazuje ona na duże skupienie studentów bielskiego ośrodka akademickiego ${ }^{5}$. Największa liczba studentów pochodzi z ośrodka, w którym jest zlokalizowana, czyli z Bielska-Białej.

Oddziaływanie bielskiego ośrodka akademickiego obejmuje głównie południową i centralną część województwa śląskiego oraz południowo-zachodnią część województwa małopolskiego (ryc. 5). Można więc stwierdzić, iż w zakresie kształtowania zasobów intelektualnych społeczeństwa bielski ośrodek akademicki spełnia funkcje ponadlokalne. Zasięg przestrzennego oddziaływania bielskich uczelni wyższych jest wyraźnie ograniczony poprzez funkcjonowanie katowickiego i krakowskiego ośrodka akademickiego, które charakteryzują się o wiele wyższym potencjałem edukacyjnym oraz liczbą szkół wyższych.

Ryc. 5. Terytorialne pochodzenie studentów bielskich szkół wyższych w roku akademickim 2008/2009

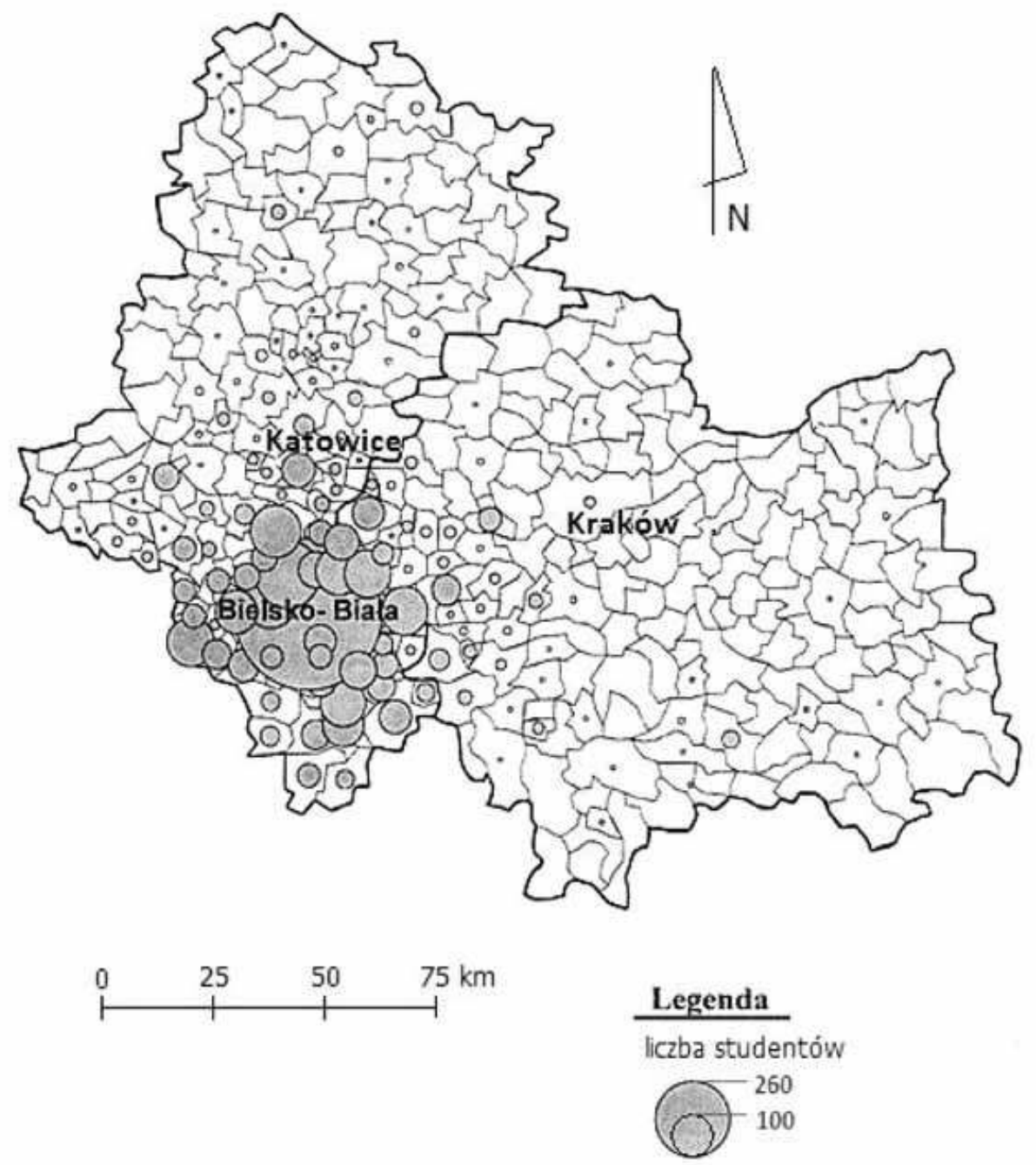

Źródło: opracowanie własne na podstawie danych jednostkowych uzyskanych w dziekanatach bielskich uczelni.

\footnotetext{
${ }^{5}$ Wskaźnik koncentracji obliczono z szeregu rozdzielczego poprzez porównanie udziału liczebności gmin udziału pochodzących z nich studentów według wzoru:

$$
\mathrm{K}_{\mathrm{o}}=\frac{\sum_{\mathrm{i}=1}^{\mathrm{n}}\left|\mathrm{o}_{\mathrm{i}}-\mathrm{s}_{\mathrm{i}}\right|}{200}
$$

gdzie: o - udział gmin i - tego wyznaczonego przedziału klasowego; s - udział studentów i - tego wyznaczonego przedziału klasowego jednostek przestrzennych (gmin).
} 
Nowe warunki ekonomiczne i kulturowe, które niesie za sobą globalizacja, wymagają przystosowania do nich gospodarki narodowej, a przede wszystkim społeczeństwa. Ważną rolę w tym procesie odgrywają ośrodki akademickie, kształtujące w warunkach lokalnych zasoby ludzkie. Nasilające się procesy globalizacji stawiają przed nimi nowe wyzwania związane z dopasowaniem struktury kształcenia do warunków rozszerzającego się rynku pracy i rozwoju gospodarki opartej na wiedzy. Szansą dla tych ośrodków może być współpraca z zagranicznymi ośrodkami naukowymi i akademickimi, wymiana studentów oraz nauczycieli akademickich, pozyskanie studentów zagranicznych oraz wprowadzenie języka angielskiego jako wykładowego. Można więc stwierdzić, że globalizacja stwarza dla rozwoju szkolnictwa wyższego wiele nowych możliwości. Mobilizuje władze poszczególnych szkół wyższych do poszukiwania nowych dróg pozyskania studentów, wprowadzania zmian i przekształceń kierunków studiów, prowadzenie studiów podyplomowych i kursów umożliwiających szybkie przekwalifikowanie.

\section{Literatura}

1. Borowiec M., 2010, Funkcjonowanie uczelni krakowskiego i rzeszowskiego ośrodka akademickiego w świetle koncepcji układów bipolarnych, Wyd. Naukowe Uniwersytetu Pedagogicznego, Kraków.

2. Denek K., 2001, Tryptyk wątków koniecznych [w:] Edukacyjne konteksty procesów globalizacji, W. Kojs (red.), Uniwersytet Śląski Filia w Cieszynie, Cieszyn.

3. Gnitecki J., 2002, Szkoła i edukacja wobec wyzwań globalnych współczesnego świata [w:] WartośćEdukacja - Globalizacja. Wybrane zagadnienia, W. Kojs (red.), UŚ Filia w Cieszynie, Cieszyn.

4. Haczek A., 2010, Rozwój i przestrzenne oddziaływanie bielskiego ośrodka akademickiego (niepublikowane).

5. Janc K., 2004, Znaczenie kapitału ludzkiego w procesach globalizacji [w:] Człowiek, region, państwo w procesach globalizacji, regionalizacji i integracji, G. Rdzanek, E. Stadtmuller (red.), Uniwersytet Wrocławski, s. 71-82.

6. Kluczyński J., 1991, Prognozy i uwarunkowania rozwoju szkolnictwa wyższego w Polsce, Instytut Polityki Naukowej i Szkolnictwa Wyższego, Wyd. Naukowe PWN, Warszawa-Lódź.

7. Musiał G., 2001, Dylematy uczelni wyższych w dobie globalizacji [w:] Edukacyjne konteksty procesów globalizacji, W. Kojs (red.), Uniwersytet Śląski Filia w Cieszynie, Cieszyn.

8. Nowakowska A., Boryczka E., 2008, Wyższe uczelnie jako czynnik kształtujący strukture przestrzenna współczesnych miast [w:] Rola wyższych uczelni w rozwoju społeczno-gospodarczym i przestrzennym miast, T. Markowski, D. Drzazga (red.), Studia KPZK PAN, z. 121, Warszawa.

9. Polak E., 2009, Globalizacja a zróżnicowanie społeczno-ekonomiczne, Wyd. Difin, Warszawa, s. 7-35.

10. Radło M.J., 2003, Wyzwanie konkurencyjności. Strategia lizbońska w poszerzonej UE, Instytut Spraw Zagranicznych, Warszawa, s. 42-62.

11. Słobodzian B., 2001, W kierunku globalizacji opartej na wiedzy. Edukacyjne konteksty procesów globalizacji, W. Kojs (red.), Uniwersytet Śląski Filia w Cieszynie, Cieszyn.

12. Zioło Z., 2008, Ekonomiczne i społeczne uwarunkowania rozwoju gospodarki opartej na wiedzy [w:] Rola przedsiębiorczości w gospodarce opartej na wiedzy, Z. Zioło, T. Rachwał (red.), „Przędsiębiorczość - Edukacja”, nr 4, Nowa Era, Zakład Przedsiębiorczości i Gospodarki Przestrzennej Instytutu Geografii Uniwersytetu Pedagogicznego w Krakowie, Warszawa-Kraków. 


\section{The Functioning of Bielsko-Biala academic Center in the Conditions of Globalization}

In the process of globalization, which is directly connected with scientific and technological progress, human capital receives special significance. Education, especially higher education, has the most important meaning as a factor leading to the improvement of the intellectual potential of societies. Educated, entrepreneurial society, which can easier be found in the new reality, is the foundation of the functioning of the global economy and raising the competitiveness of individual regions and countries.

The article discusses the functioning of the Bielsko-Biala academic center in the conditions of the globalization. It presents changes in the educational potential of the center in the years 1969-2009. Particular attention was paid to changes in the educational structure of the BielskoBiala academic center and its adaptation to the conditions of modern economy. In addition, the range of influence of the Bielsko-Biala academic center was defined based on the permanent residence of the students in the academic year 2008/2009.

The results of this study assess the impact of globalization on the functioning of the academic centers, as well as the role of the Bielsko-Biala academic center in the development of human capital in local conditions. 